\title{
PENGARUH PENERAPAN STANDAR AKUNTANSI PEMERINTAHAN BERBASIS AKRUAL, KOMPETENSI SUMBER DAYA MANUSIA DAN PENGENDALIAN INTERN TERHADAP KUALITAS LAPORAN KEUANGAN PEMERINTAH KABUPATEN GIANYAR
}

\section{(STUDI EMPIRIS PADA ORGANISASI PERANGKAT DAERAH KABUPATEN GIANYAR)}

\author{
Putu Cita Ayu ${ }^{1)}$ \\ Ni Putu Ayu Kusumawati ${ }^{2}$ \\ Universitas Hindu Indonesia, email: citaayu87@gmail.com
}

\begin{abstract}
This study aims to determine the effect of the application of accrual-based government accounting standards, human resource competencies and internal control on the quality of financial statements of the Gianyar Regency government. The type of data used in this study is a type of quantitative data while the data sources used in this study are primary and secondary data sources. The population used in this study was 36 departments in the Gianyar Regency Regional Organizations Organization. The sample in this study used a purposive sampling method, with a sample of 91 respondents working in the finance department. Data was collected using the questionnaire method. The data analysis technique used in this study is multiple linear regression analysis. The results showed that the application of accrual-based government accounting standards, human resource competence and internal control had a positive effect on the quality of local government financial reports in Gianyar Regency. This shows that the higher the application of accrualbased government accounting standards, human resource competencies and internal control, the higher the quality of local government financial reports in Gianyar Regency.
\end{abstract}

Keywords: Quality of Financial Statements, Accrual-Based Government Accounting Standards, Competence of Human Resources, Internal Control.

\section{PENDAHULUAN}

Di Indonesia, laporan keuangan pemerintah sangat menarik untuk dikaji, mengingat semakin kuatnya tuntutan akuntabilitas atas lembaga-lembaga publik, baik pusat maupun daerah. Kenyataannya di dalam laporan keuangan pemerintah, masih banyak disajikan data yang tidak sesuai yang berhasil ditemukan oleh Badan Pemeriksa Keuangan (BPK). Laporan keuangan pemerintah memiliki fungsi yang sangat penting. Salah satu fungsinya ialah laporan keuangan merupakan gambaran kondisi suatu pemerintah dan sebagai salah satu cara bagi pemerintah daerah untuk mewujudkan akuntabilitas keuangannya. 
Untuk peningkatan kualitas laporan keuangan, pemerintah merevisi PP No. 24 Tahun 2005 dengan mengeluarkan PP No. 71 Tahun 2010 tentang Standar Akuntansi Pemerintah (SAP) yang berbasis akrual. Penerapan akuntansi berbasis akrual diperlukan untuk menghasilkan pengukuran kinerja yang lebih baik, serta untuk memfasilitasi manajemen keuangan/aset yang lebih transparan dan akuntabel. Adapun tujuan penggunaan basis akrual yaitu: meningkatkan efisiensi dan efektivitas (penganggaran, akuntansi dan pelaporan), meningkatkan pengendalian fiskal (manajemen asset), meningkatkan akuntanbilitas dalam program penyediaan barang dan jasa oleh pemerintah, informasi yang lebih lengkap bagi pemerintah untuk pengambilan keputusan, mereformasi sistem anggaran belanja dan transparansi yang lebih luas atas biaya pelayanan yang dilakukan oleh pemerintah. Akuntansi berbasis akrual mengakui pendapatan dan belanja (biaya) bukan pada saat kas diterima atau dibayarkan, tetapi pada saat transaksi terjadi.

Dalam penyusunan laporan keuangan yang berkualitas tentu membutuhkan Sumber Daya Manusia yang kompeten dan memahami aturan penyusunan laporan keuangan dengan standar akuntansi pemerintahan. Kompetensi Sumber Daya Manusia adalah kemampuan untuk melaksanakan fungsi-fungsi untuk mencapai tujuannya secara efektif dan efisien. Sumber Daya Manusia merupakan faktor penting demi terciptanya laporan keuangan yang berkualitas. Adapun tujuan dari kegiatan pengembangan Sumber Daya Manusia menurut Schuler (1992), yaitu: Mengurangi dan menghilangkan kinerja yang buruk, Meningkatkan produktivitas, Meningkatkan fleksibilitas dari angkatan kerja, Meningkatkan komitmen karyawan dan Mengurangi turn over dan absensi. Dalam hal ini adanya Kompetensi Sumber Daya Manusia mendasari seseorang mencapai kinerja yang tinggi dalam pekerjaannya serta memiliki peranan yang sangat penting untuk merencanakan, melaksanakan, dan mengendalikan entitas yang bersangkutan. 
Laporan keuangan pemerintah daerah yang baik juga sangat ditentukan oleh seberapa baik pengendalian internal yang dimiliki institusi pemerintah daerah. Pengendalian intern yang lemah menyebabkan sulitnya mendeteteksi kecurangan/ketidakakuratan proses akuntansi sehingga bukti audit yang diperoleh dari data akuntansi menjadi tidak kompeten. Pengendalian Intern atau kontrol intern didefinisikan sebagai suatu proses, yang dipengaruhi oleh sumber daya manusia dan sistem teknologi informasi, yang dirancang untuk membantu organisasi mencapai suatu tujuan atau objektif tertentu. Pengendalian intern merupakan suatu cara untuk mengarahkan, mengawasi, dan mengukur sumber daya suatu organisasi. Pengendalian Intern berperan penting untuk mencegah dan mendeteksi penggelapan (fraud) dan melindungi sumber daya organisasi baik yang berwujud (seperti mesin dan lahan) maupun tidak berwujud (seperti reputasi atau hak kekayaan intelektual seperti merek dagang). Adapun tujuan pengendalian intern adalah menjamin manajemen perusahaan atau organisasi atau entitas agar tujuan perusahaan yang ditetapkan akan dapat dicapai, laporan keuangan yang dihasilkan perusahaan dapat dipercaya dan kegiatan perusahaan sejalan dengan hukum dan peraturan yang berlaku. Pengendalian intern dapat mencegah kerugian atau pemborosan pengolahan sumber daya perusahaan. Pengendalian intern dapat menyediakan informasi tentang bagaimana menilai kinerja perusahaan dan manajemen perusahaan serta menyediakan informasi yang akan digunakan sebagai pedoman dalam perencanaan. Pengendalian intern dapat mencegah kerugian atau pemborosan pengolahan sumber daya perusahaan. Committee of Sponsoring Organizations of the Treatway Commission (COSO) memperkenalkan adanya lima komponen Pengendalian Intern yang meliputi Lingkungan Pengendalian (Control Environment), Penilaian Risiko (Risk Assesment), Aktivitas Pengendalian (Control Procedure), Pemantauan (Monitoring), serta Informasi dan Komunikasi (Information and Communication). 
Pemilihan ini dilakukan di Pemerintahan Kabupaten Gianyar dikarenakan pada tahun 2009-2013 BPK RI memberikan opini Wajar Dengan Pengecualian dalam penyajian laporan keuangan pemerintah daerah Kabupaten Gianyar. Namun dari tahun 2014-2017 pemerintah Kabupaten Gianyar telah mendapatkan opini dari BPK RI yaitu Wajar Tanpa Pengecualian empat kali berturut-turut. Meskipun pemerintah Kabupaten Gianyar telah mendapatkan opini wajar tanpa pengecualian namun dari pelaksanaan pemeriksaan di lapangan, BPK masih menemukan beberapa kelemahan dalam sistem pengendalian internal dan kepatuhan terhadap peraturan perundang-undangan. Opini BPK merupakan salah satu indikator yang digunakan oleh para pemakai kepentingan (stakeholders) untuk mendapatkan tingkat kepercayaan atas sebuah laporan keuanganyang disajikan.

Akuntansi berbasis akrual merupakan suatu basis akuntansi di mana transaksi ekonomi dan peristiwa lainnya diakui, dicatat, dan disajikan dalam laporan keuangan pada saat terjadinya transaksi tersebut, tanpa memperhatikan waktu kas atau setara kas diterima atau dibayarkan. Dalam akuntansi berbasis akrual, waktu pencatatan (recording) sesuai dengan saat terjadinya arus sumber daya.

Salah satu hasil studi yang dilakukan oleh IFAC Public Sector Committee (2002) menyatakan bahwa pelaporan berbasis akrual bermanfaat dalam mengevaluasi kinerja pemerintah terkait biaya jasa layanan, efisiensi, dan pencapaian tujuan. Dengan pelaporan berbasis akrual, pengguna dapat mengidentifikasi posisi keuangan pemerintah dan perubahannya, bagaimana pemerintah mendanai kegiatannya sesuai dengan kemampuan pendanaannya sehingga dapat diukur kapasitas pemerintah yang sebenarnya. Akuntansi pemerintah berbasis akrual juga memungkinkan pemerintah untuk mengidentifikasi kesempatan dalam menggunakan sumber daya masa depan dan mewujudkan pengelolaan yang baik atas sumber daya tersebut. Hal ini didukung oleh penelitian yang dilakukan oleh 
Ida Ayu Enny Kiranayanti dan Ni Made Adi Erawati (2016) dalam penelitiannya menunjukkan bahwa kompetensi sumber daya manusia, sistem pengendalian intern dan pemahaman atas regulasi sistem akuntansi pemerintahan berbasis akrual mempunyai pengaruh positif dan signifikan terhadap kualitas laporan keuangan pemerintah daerah. Rizki Mardiana dan Heru Fahlevi (2017) dalam penelitiannya yang menunjukkan bahwa pemahaman akuntansi, pengendalian internaldan efektifitas penerapan SAP berbasis akrual secara bersama-sama berpengaruh terhadap kualitas laporan keuangan. Franta Eveline (2016) dalam penelitiannya menyatakan bahwa standar akuntansi pemerintah berbasis akrual, sistem informasi akuntansi, kualitas sumber daya manusia, pengendalian internal dan komitmen organisasi berpengaruh signifikan terhadap kualitas laporan keuangan, maka dapat ditarik hipotesis sebagai berikut:

\section{H1 : Penerapan Standar Akuntansi Pemerintahan Berbasis Akrual berpengaruh positif terhadap Kualitas Laporan Keuangan.}

Kompetensi Sumber Daya Manusia adalah kemampuan yang dimiliki seseorang yang berhubungan dengan pengetahuan, keterampilan dan karakteristik kepribadian yang mempengaruhi secara langsung terhadap kinerjanya yang dapat mencapai tujuan yang diinginkan. Sumber Daya Manusia merupakan faktor terpenting dalam menciptakan laporan keuangan yang berkualitas, penyiapan dan penyusunan laporan keuangan memerlukan Sumber Daya Manusia yang memiliki kompetensi serta menguasai akuntansi pemerintahan. Apabila sumber daya manusia yang melaksanakan sistem akuntansi memiliki kualitas yang disyaratkan, maka akan menghasilkan kualitas laporan keuangan yang baik.

Hal ini didukung oleh beberapa penelitian yang dilakukan oleh As Syifa Nurillah dkk,.(2014) dalam penelitiannya yang menunjukkan bahwa kompetensi sumber daya manusia, penerapan sistem akuntansi keuangan daerah, pemanfaatan teknologi informasi 
dan sistem pengendalian intern berpengaruh positif dan signifikan terhadap kualitas laporan keuangan. Juliani Cahya Kartika dan Drs. Eddy Budiono, MM., QIA (2015) dalam penelitiannya menunjukkan bahwa secara simultan kompetensi seumber daya manusia, implementasi sistem akuntansi instansidan sistem pengendalian intern pemerintah berpengaruh terhadap kualitas laporan keuangan. Freddie Lasmara dkk,. (2016) yang menbuktikan bahwa kompetensi sumber daya manusia, perangkat pendukung dan peran auditor internal secara bersama-sama berpengaruh positif terhadap kualitas laporan keuangan, maka dapat ditarik hipotesis sebagai berikut:

\section{H2 : Kompetensi Sumber Daya Manusia berpengaruh positif terhadap Kualitas}

\section{Laporan Keuangan.}

Pengendalian Intern adalah metode, proses, dan kebijakan yang didesain oleh dewan komisaris, manajemen dan personel lain untuk memberi jaminan yang memadai atas tercapainya efisiensi dan efektifitas operasi, keandalan laporan keuangan, dan kepatuhan terhadap hukum dan peraturan yang berlaku. Sistem Pengendalian Intern adalah proses yang integral pada tindakan dan kegiatan yang dilakukan secara terus menerus oleh pimpinan dan seluruh pegawai untuk memberikan keyakinan memadai atas tercapainya tujuan organisasi melalui kegiatan yang efektif dan efisien keandalan pelaporan keuangan, pengamanan aset negara, dan ketaatan terhadap peraturan perundang-undangan. Proses pengendalian Intern yang baik dan sesuai dengan kebutuhan serta kondisi organisasi akan menimbulkan semangat organisasi untuk terus melakukan upaya dalam menjaga kualitas laporan keuangan organisasi.

Hal ini didukung oleh beberapa penelitian yang dilakukan oleh Tuti Herawati (2014) dalam penelitiannya menunjukkan bahwa sistem pengendalian intern berpengaruh positif dan signifikan terhadap kualitas laporan keuangan. Febriyani Moha, dkk (2017) dalam 
penelitianyya yang menunjukkan bahwa sistem pengendalian intern dan prinsip pengelolaan keuangan daerah secara simultan berpengaruh positif dan signifikan terhadap kualitas laporan keuangan. Teuku Fahrian Nagor, dkk (2015) dalam penelitiannya menunjukkan bahwa penerapan sistem pengendalian intern dan penerapan prinsip pengelolaan keuangan daerah baik secara simultan maupun secara parsial berpengaruh terhadap kualitas laporan keuangan daerah, maka dapat ditarik hipotesis sebagai berikut:

\section{H3 : Pengendalian Intern berpengaruh positif terhadap Kualitas Laporan Keuangan.}

\section{METODE PENELITIAN}

Penelitian ini dilakukan pada Organisasi Perangkat Daerah (OPD) Kabupaten Gianyar. Obyek penelitian ini adalah penerapan standar akuntansi pemerintahan berbasis akrual, kompetensi sumber daya manusia dan pengendalian intern terhadap kualitas laporan keuangan kabupaten Gianyar.

Variabel Bebas (Independen) adalah variabel yang mempengaruhi atau yang menjadi sebab perubahan timbulnya variabel terikat (Kerlinger 2006: 58). Penelitian ini terdiri dari tiga variabel independen, yaitu: Standar Akuntansi Pemerintahan Berbasis Akrual (X1), Kompetensi Sumber Daya Manusia (X2) dan pengendalian intern (X3). Variabel Terikat (Dependen) adalah variabel yang dipengaruhi atau yang menjadi akibat adanya variabel bebas (Kerlinger 2006: 58).Variabel terikat dalam penelitian ini yaitu kualitas laporan keuangan (Y).

Penelitian ini menggunakan jenis data kuantitatif. Sumber data yang digunakan dalam penelitian ini adalah sumber data primer dan data sekunder. Dimana data primer diperoleh dari jawaban kuesioner dari responden secara langsung yang dikirim kepada pegawai yang bekerja di OPD Kabupaten Gianyar. Sedangkan data sekunder diperoleh dari jurnal-jurnal, buku dan referensi lainnya. 
Populasi adalah wilayah generalisasi yang terdiri atas, obyek/subjek yang mempunyai kuantitas \& karakteristik tertentu yang ditetapkan oleh peneliti untuk dipelajari dan kemudian ditarik kesimpulannya (Sugiyono 2017,80). Populasi yang digunakan dalam penelitan ini yaitu seluruh pegawai di Organisasi Perangkat Daerah Kabupaten Gianyar yang berjumlah 6.174 orang. Metode penentuan sampel dalam penelitian ini adalah purposive sampling. Purposive Sampling adalah teknik penentuan sampel dengan pertimbangan tertentu (Sugiyono, 2017:85). Kriteria penentuan sampel dalam penelitian ini adalah Seluruh pegawai yang bekerja di Organisasi Perangkat Daerah Kabupaten Gianyar, berpendidikan minimal SLTA, pegawai yang bekerja sebagai Kasubbag Keuangan dan Bendahara serta pegawai yang bekerja minimal satu tahun di bidang Keuangan.

Metode pengumpulan data yang digunakan dalam penelitian ini adalah metode kuesioner, yaitu metode pengumpulan data yang dilakukan dengan cara memberi seperangkat pertanyaan tertulis kepada responden untuk dijawab (Sugiyono, 2017:142).

\section{HASIL DAN PEMBAHASAN}

Pengujian hipotesis dalam penelitian menggunakan analisis Regresi Linier Berganda. Hasil perhitungan di sajikan pada tabel 1

\section{Tabel 1 Tabulasi Output SPSS}

\begin{tabular}{|l|l|l|l|}
\hline \multicolumn{1}{|c|}{ Variabel } & $\begin{array}{c}\text { Standardized } \\
\text { Beta }\end{array}$ & $\begin{array}{c}\text { Probabilitas } \\
(\text { sig. })\end{array}$ & Keterangan \\
\hline Konstanta & 1.775 & 0.532 & \\
\hline SAP Akrual (SA) & 0.343 & 0.000 & Signifikan \\
\hline Kompetensi SDM (KS) & 0.335 & 0.000 & Signifikan \\
\hline Pengendalian Intern (PI) & 0.628 & 0.000 & Signifikan \\
\hline Adjusted R Square & 0.562 & & \\
\hline F Statistik & 39.559 & & \\
\hline Probabilitas (p-value) & 0,000 &
\end{tabular}




\begin{tabular}{|l|l|}
\hline Variabel Dependen & Kualitas Laporan Keuangan (KL) \\
\hline
\end{tabular}

Sumber: Data diolah

Nilai adjusted $\mathrm{R}$ square sebesar 0,562 menunjukkan bahwa 56,2\% variasi nilai Kualitas Laporan Keuangan dapat dijelaskan oleh faktor-faktor Standar Akuntansi Pemerintahan Berbasis Akrual, Kompetensi Sumber Daya Manusia dan Pengendalian Intern. Sedangkan sisanya sebesar $43,8 \%$ dipengaruhi oleh faktor lain yang tidak diamati dalam penelitian ini.

\section{Pengaruh Standar Akuntansi Pemerintahan Berbasis Akrual pada Kualitas Laporan}

\section{Keuangan}

Berdasarkan hasil penelitian, didapat nilai koefisien regresi Standar Akuntansi Pemerintahan Berbasis Akrual sebesar 0,343 dengan signifikansi 0,000. Hal ini menunjukkan bahwa Standar Akuntansi Pemerintahan Berbasis Akrual berpengaruh positif terhadap Kualitas Laporan Keuangan. Nilai signifikansi Standar Akuntansi Pemerintahan Berbasis Akrual adalah $0,000<0,05$, hal ini menunjukkan bahwa Standar Akuntansi Pemerintahan berpengaruh signifikan terhadap Kualitas Laporan Keuangan. Hasil penelitian memberikan makna bahwa semakin tinggi Standar Akuntansi Pemerintahan Berbasis Akrual maka kecenderungan Kualitas Laporan Keuangan juga semakin tinggi. Dengan demikian, hipotesis pertama (H1) yang menyatakan bahwa Penerapan Standar Akuntansi Pemerintahan Berbasis Akrual berpengaruh terhadap Kualitas Laporan Keuangan diterima.

\section{Pengaruh Kompetensi Sumber Daya Manusia pada Kualitas Laporan Keuangan}

Berdasarkan hasil penelitian, didapat nilai koefisien regresi Kompetensi Sumber Daya Manusia sebesar 0,335 dengan signifikansi 0,000.Hal ini menunjukkan bahwa Kompetensi Sumber Daya Manusia berpengaruh positif terhadap Kualitas Laporan Keuangan. Nilai signifikansi Kompetensi Sumber Daya Manusia adalah 0,000 < 0,05, hal 
ini menunjukkan bahwa Kompetensi Sumber Daya Manusia berpengaruh signifikan terhadap Kualitas Laporan Keuangan. Hasil penelitian ini memberikan makna bahwa semakin tinggi Kompetensi Sumber Daya Manusia maka kecenderungan Kualitas Laporan Keuangan juga semakin tinggi. Dengan demikian, hipotesis kedua $(\mathrm{H} 2)$ yang menyatakan bahwa Kompetensi Sumber Daya Manusia berpengaruh terhadap Kualitas Laporan Keuangan diterima.

\section{Pengaruh Kompetensi Sumber Daya Manusia pada Kualitas Laporan Keuangan}

Berdasarkan hasil penelitian, didapat nilai koefisien regresi Kompetensi Sumber Daya Manusia sebesar 0,335 dengan signifikansi 0,000.Hal ini menunjukkan bahwa Kompetensi Sumber Daya Manusia berpengaruh positif terhadap Kualitas Laporan Keuangan. Nilai signifikansi Kompetensi Sumber Daya Manusia adalah 0,000 < 0,05, hal ini menunjukkan bahwa Kompetensi Sumber Daya Manusia berpengaruh signifikan terhadap Kualitas Laporan Keuangan. Hasil penelitian ini memberikan makna bahwa semakin tinggi Kompetensi Sumber Daya Manusia maka kecenderungan Kualitas Laporan Keuangan juga semakin tinggi. Dengan demikian, hipotesis kedua (H2) yang menyatakan bahwa Kompetensi Sumber Daya Manusia berpengaruh terhadap Kualitas Laporan Keuangan diterima.

\section{KESIMPULAN DAN SARAN}

Berdasarkan hasil pembahasan analisis data melalui pembuktian terhadap hipotesis, maka simpulan yang dapat diambil adalah sebagai berikut: (1). Standar Akuntansi Pemerintahan Berbasis Akrual berpengaruh positif terhadap Kualitas Laporan Keuangan. Hal ini menunjukkan bahwa semakin tinggi Standar Akuntansi Pemerintahan Berbasis Akrual maka Kualitas Laporan Keuangan juga akan meningkat. (2). Kompetensi Sumber Daya Manusia berpengaruh positif terhadap Kualits Laporan Keuangan. Hal ini 
menunjukkan bahwa semakin tinggi Kompetensi Sumber Daya Manusia maka Kualitas Laporan Keuangan juga akan meningkat. (3). Pengendalian Intern berpengaruh positif terhadap Kualitas Laporan Keuangan. Hal ini menunjukkan bahwa semakin tinggi Pengendalian Intern maka Kualitas Laporan Keuangan juga akan meningkat.

Berdasarkan simpulan tersebut, maka saran yang dapat diberikan adalah sebagai berikut: (1). Untuk mengimplementasikan PP No. 71 tahun 2010 tentang standar akuntansi pemerintahan berbasis akrual, disarankan kepada pemerintah daerah untuk lebih meningkatkan pemahaman pegawai atas standar akuntansi pemerintahan berbasis akrual. (2). Sebaiknya pemerintah daerah memberikan pelatihan-pelatihan kepada aparatur pemda secara rutin dan berkesinambungan agar pegawai memiliki kualitas yang baik sehingga akan berdampak pada kualitas laporan keuangan yang semakin baik. (3). Dalam pengendalian intern yang ada pada pemerintahan, sebaiknya Standard Operating Procedure (SOP) yang sudah ada agar lebih ditingkatkan lagi dan selalu memperbaiki SOP sesuai dengan perkembangan dan membukukannya ketika ada perubahan untuk menjadikan SOP sebagai alat untuk bekerja dan mencapai tujuan. (4). Kualitas laporan keuangan pemerintah daerah lebih ditingkatkan lagi dengan cara menjalankan penerapan standar akuntansi pemerintahan berbasis akrual, kompetensi sumber daya manusia dan pengendalian intern secara bersamaan agar terciptanya kualitas laporan keuangan yang baik.

\section{DAFTAR PUSTAKA}

A.A Anwar Prabu Mangkunegara. 2012.Manajemen Sumber Daya Manusia. Bandung: PT. Remaja Rosdakarya.

Abdul dan Abdullah. 2006. Hubungan dan Masalah Keagenan di Pemerintah Daerah. Jurnal Akuntansi Pemerintahan, Volume 2, Nomor 1, Hal.: 53-64, 2006

Arens, A. A., Elder, R. J., \& Beasley, M. S. 2008. Auditing dan Jasa Assurance Jilid 1. Jakarta: Erlangga. 
Bergman dan Lane. 1990. Public policy in a principal-agent framework. Journal of Theoretical Politics 2(3): 339-352.

Danang Sunyoto, (2012). Uji Validitas dan Reliabilitas, Asumsi Klasik untuk Kesehatan. Cetakan 1. Yogyakarta: Nuha Medika.

Edy, Sutrisno. 2012. Manajemen Sumber Daya Manusia. Jakarta: Kencana.

Eveline, Franta. 2016. Pengaruh SAP Berbasis Akrual, Sistem Informasi Akuntansi, Kualitas SDM, Pengendalian Internal dan Komitmen Organisasi terhadap Kualitas Laporan Keuangan di Badan Nasional Penanggulangan Bencana. Vol.16, No.1.

Ghozali, Imam. 2005. Aplikasi Analisis Multivariate dengan SPSS. Semarang: Badan Penerbit UNDIP.

Ghozali, Imam. 2006. Aplikasi Analisis Multivariate dengan Program SPSS (Edisi Ke 4). Semarang:Badan Penerbit Universitas Diponegoro.

Ghozali, Imam. 2009. Aplikasi Analisis Multivariate dengan Program SPSS. Semarang : UNDIP

Ghozali, Imam. 2011. Aplikasi Analisis Multivariate Dengan Program SPSS. Semarang: Badan Penerbit Universitas Diponegoro.

Ghozali, Imam. 2013. Aplikasi Analisis Multivariate dengan Program IBM SPSS 21 Edisi 7. Semarang: Penerbit Universitas Diponegoro.

Herawati, Tuti. 2014. Pengaruh Sistem Pengendalian Intern Terhadap Kualitas Laporan Keuangan (Survei Pada Organisasi Perangkat Daerah Pemda Cianjur). Jurnal Akuntansi. Vol.XI, No.1.

Ikatan Akuntansi Indonesia (IAI). 2012. Standar Akuntansi Keuangan. Jakarta: Salemba Empat.

Kartika, Juliani Cahya dan Eddy Budiono. 2015. Pengaruh Kompetensi Sumber Daya Manusia, Implementasi Sistem Akuntansi Instansi, Dan Sistem Pengendalian Internal Pemerintah Terhadap Kualitas Laporan Keuangan (Studi Kasus pada Satuan Kerja di Lingkungan Kementerian Pertahanan Republik Indonesia). Vol.2, No.3. Hal: 3359-3366. Universitas Telkom.

Kerlinger. 2006. Asas-Asas Penelitian Behaviour. Edisi 3, Cetakan 7. Yogyakarta: Gadjah Mada University Press.

Kiranayanti, Ida Ayu Enny dan Ni Made Adi Erawati. 2016. Pengaruh Sumber Daya Manusia, Sistem Pengendalian Intern, Pemahaman Basis Akrual terhadap Kualitas Laporan Keuangan Daerah. Jurnal Akuntansi. Vol.16, No.2. Hal: 1290-1318. Universitas Udayana.

Lasmara, Freddie dan Sri Rahayu. 2016. Pengaruh Kompetensi Sumber Daya Manusia, Perangkat Pendukung dan Peran Auditor Internal terhadap Kualitas 
Laporan Keuangan Pemerintah Daerah Kabupaten Kerinci. Jurnal Perspektif Pembiayaan dan Pembangunan Daerah. Vol.3, No.4. Universitas Jambi.

Mardiana, Rizki dan Heru Fahlevi. 2017. Pengaruh Pemahaman Akuntansi, Pengendalian Internal dan Efektivitas Penerapan SAP Berbasis Akrual terhadap

Kualitas Laporan Keuangan (Studi pada Satuan Perangkat Kerja Kota Banda Aceh). Jurnal Ilmiah Mahasiswa Ekonomi Akuntansi (JIMEKA). Vol.2, No.2. Hal: 30-38. Universitas Syiah Kuala.

Mardiasmo, 2006. Perwujudan Transparansi dan Akuntabilitas Publik melalui Akuntansi terhadap Keuangan Negara. Universitas Gunadarma.

Mardiasmo. 2002. Akuntansi Sektor Publik. Penerbit Andi. Yogyakarta.

Miriam Budiarjo. 1994. Demokrasi di Indonesia Demokrasi Parlementer dan Demokrasi Pancasila. Jakarta: Gramedia Pustaka Utama

Moeheriono. 2010. Pengukuran Kinerja Berbasis Kompetensi. Surabaya: Ghalia Indonesia.

Moha, Febriyani. Lintje Kalangi. Jessy D.L Warongan. 2017. Pengaruh Sistem Pengendalian Intern Dan Prinsip Pengelolaan Keuangan Daerah Terhadap Kualitas Laporan Keuangan Pada Pemerintah Daerah Kabupaten Bolaang Mongondow Selatan. Jurnal EMBA. Vol.5, No.2. Hal: 1359-1370. Universitas Sam Ratulangi.

Mulyadi. 2013. Sistem Akuntansi. Jakarta: Salemba Empat

Nagor, Teuku Fahrian. Darwanis. Syukriy Abdullah. 2015. Pengaruh Penerapan Sistem Pengendalian Intern dan Penerapan Prinsip Pengelolaan Keuangan Daerah terhadap Kualitas Laporan Keuangan Pemerintah Daerah Kabupaten Aceh Barat. Jurnal Magister Akuntansi. Vol.4, No.1. Hal: 72-79. Universitas Syiah Kuala.

Nurillah, As Syifa dan Dul Muid. 2014. Pengaruh Kompetensi Sumber Daya Manusia, Penerapan Sistem Akuntansi Keuangan Daerah (SAKD), Pemanfaatan

Teknologi Informasi, dan Sistem Pengendalian Intern terhadap Kualitas Laporan Keuangan Pemerintah Daerah (Studi Empiris Pada SKPD Kota Depok). Jurnal Akuntansi. Vol.3, No.2. Universitas Diponegoro.

Peraturan Pemerintah No. 60 Tahun 2008. Sistem Pengendalian Intern Pemerintah.

Peraturan Pemerintah No. 71 Tahun 2010. Kerangka Konseptual Akuntansi Pemerintahan.

Peraturan Pemerintah No. 71 Tahun 2010. Standar Akuntansi Pemerintahan Berbasis Akrual.

Rai, Gusti Agung. 2008. Audit Kinerja Pada Sektor Publik: Konsep Praktik Studi Kasus. Penerbit: Salemba Empat 
Ramandei, P. 2009. Pengaruh Karakteristik Sasaran Anggaran dan Sistem Pengendalian Internterhadap Kinerja Manajerial. Tesis, Universitas Diponegoro.

Republik Indonesia. Undang-undang No. 17 Tahun 2003. tentang Keuangan Negara.

Republik Indonesia. Undang-undang No. 23 Tahun 2014. tentang Pemeritah Daerah.

Schuler, S. R. 1992. Strategic Human Resource Management : Linking the People with the Strategic Needs of The Business. Organizational Dynamics, Summe, $\quad 21(1): 18$.

Sugiyono, 2009, Metode Penelitian Kuantitatif, Kualitatif dan $R \& D$, Bandung: Alfabeta.

Sugiyono. 2017. Metode Penelitian Kuantitatif, Kualitatif, dan R\&D. Bandung: Alfabeta.

Wibowo, 2007, Manajemen Kinerja, Jakarta :Raja Grafindo Persada. 